\title{
Exclusive Representation of Employee Shareholders in the Board: Issues and Economic Consequences
}

\author{
Tarek Ben Noamene $e^{1} \&$ Slim Ahmed Hassairi ${ }^{2}$ \\ ${ }^{1}$ G.R.M. (Management Research Group), The Institute of Business Administration of Nice (IAE), France \\ ${ }^{2}$ Department of Accounting and Finance, The Higher Institute of Accountancy and Business Administration \\ (ISCAE), The University of Manouba, Tunisia \\ Correspondences: Tarek Ben Noamene, The Institute of Business Administration of Nice (IAE), 24 Avenue des \\ Diables bleus, 06300 Nice, France. E-mail: tarek.noa@gmail.com \& Slim Ahmed Hassairi, The Higher Institute \\ of Accountancy and Business Administration (ISCAE), The University of Manouba, Tunisia. E-mail: \\ slim.hassairi@univ-cezanne.fr
}

Received: October 7, 2012

Accepted: November 7, 2012

Online Published: November 19, 2012

doi:10.5539/ibr.v5n12p212

URL: http://dx.doi.org/10.5539/ibr.v5n12p212

\begin{abstract}
This research proposes to study the consequences of "exclusive" representation of employee shareholders in the board of directors or trustees regarding the company's performance. The literature is controversial on the efficiency of management by directors representing employee shareholders. However, the work does not distinguish between representing employee shareholders only (outcome from an association of employee shareholders or a FCPE (company investment fund) of those elected by all employee or derived form of a labour organization. Our empirical study based on a sample of companies in the SBF 250, highlights the negative influence of the presence of directors representing employee shareholders on the economic performance of the firm.
\end{abstract}

Keywords: employee ownership, corporate governance, management board, corporate performance

\section{Introduction}

Employee ownership is a mechanism that allows employee to acquire the securities of their companies at preferential prices, while benefiting from a social framework and attractive tax (Desbrières, 2002).

In France, the practice of employee ownership has become widespread during the 1980 thanks to the privatization programs undertaken by the State. Today, one French employee of ten is a shareholder in the company or, roughly, three million of employee shareholders in 2010 (Note1).

The development of mechanisms of employee ownership has increased in recent years, mainly because of the legislative framework changes.

"Indeed, the law dated December 30, 2006 came to devote the increased growth of employee ownership on the representation of employee shareholders on the board of directors or of trustees of companies with significant employee ownership (at least 3\% of the capital is held by employee). Indeed, under article 32 of law of 30 December 2006, boards of directors or of trustees of listed companies are required to accommodate at least one director, non-union affiliation (non derived form of a labour organization), to represent employee shareholders" (Hollandts \& Aubert, 2011).

The particularity of the French case is that companies can have both an ordinary employee representation in the supervisory bodies (representation mandatory or optional), and a representation of employee shareholders under the law dated December 30, 2006. However, some directors representing the shareholders, though elected by employee shareholders, represent one additional salaried director, because of their union affiliation (Hollandts \& Guedri, 2007). It is therefore necessary to differentiate between directors representing ordinary employee, the directors representing employee shareholders but elected by all employees and the directors representing exclusively employee shareholders issued from an association of employee shareholders or from a company investment fund.

It is this last category of "exclusive" representatives which will be the subject of our study. Indeed, the literature 
considers that the presence of shareholders directors of the company promotes aligning their interests with those of external shareholders (Jensen \& Warner, The distribution of power among corporate managers, 1988). With effective control of the managers, directors would work in their own interest, identified with that of other shareholders. The agency theory emphasizes the importance of stock ownership by members of the board on the effectiveness of inspections carried out within that body (Hillman \& Dalziel, 2003).

The contribution of this paper is, therefore, to determine the impact of an exclusive representation of employee shareholders in the board on the economic performance of the firm. In this regard, we will show in the first instance, through a literature review, the ambivalent impact and role ambiguous (Hollandts \& Guedri, 2007) of directors representing employee shareholders, we will conduct as a second step, an empirical examination of a sample of French companies from the SBF250.

\section{The Representation of Employee Shareholders in the Corporate Governance: Theoretical Analysis}

For several years the problems of corporate governance have focused on the role and functioning of the board (Charreaux, 1997). This is governing bodies for both decision and control; the composition and structure continue to be subject to changes and reforms (Wirtz, 2000).

The task of the board, through its members (internal and external directors), is to align the interests of executives with those of shareholders (Fama \& Jensen, 1983).

However, the effectiveness of its role depends on the alignment of its members' interests with those of shareholders (Fama, 1980; Jensen \& Meckling, 1976).

As part of employee ownership, there is a question of representation of new internal ownership: employee. To this end, the literature in corporate governance is controversial on the role of the directors representing employee shareholders.

Some authors support the idea of a government by employee shareholders, in case they reinforce the control by external shareholders on managers (Desbrières, 2002; D’Arcimoles \& Trébucq, 2003).

Others consider the representation of employee shareholders in the supervisory bodies, as an additional opportunity for the executives rooting (Gamble, 2000; Gharbi \& Lepers, 2008; Hollandts, Guedri, \& Aubert, 2011).

We develop, thus, two competing theories: according to the first, employee shareholders enhance the effectiveness of corporate governance and foster the convergence of interests of employee with those of stakeholders (Desbrières, 2002).

According to the second argument, the participation of employee shareholders in decision-making facilitates managers rooting and workers at the expense of external shareholders (Gamble, 2000; Gharbi \& Lepers, 2008).

\subsection{The Employee Ownership as Mechanism of Corporate Governance}

The system of traditional corporate governance, based on agency theory, considered the "property" as the basic dimension to exercise control of the firm. Thus, the owner holds two types of rights: the right to control the firm and the right to the residual annuity (Hansmann, 1996).

The shareholders are the owners of capital. They occupy a prominent position within the company and ensure control over the management and employee. They naturally have the right to control the company and direct its operation, since they are the only ones to bear the risk of their financial investment (Aglietta \& Reberioux, Dérives du capitalisme financier, 2004).

In the presence of employee ownership, employee faces a greater risk than external shareholders, because they are, at same time, providers of human capital and financial resources (Blair, Kruse, \& Blasi, 2000).

On the other hand, "regarding other shareholders, employee have an output capacity much lower, the labour market is less liquid than the financial market, especially due to the low redeploy ability of human capital and intensity of the specification with respect to the assets of the firm" (Hollandts \& Aubert, 2011).

Therefore, if one considers that the risk argument is the one which must be used to define a hierarchy shareholder in the company, then the employee shareholders should occupy the top of the hierarchy and therefore have a representation in the decision-making bodies (Hollandts, Guedri, \& Aubert, 2011).

As noted Desbrières (2002, p. 259) "employee ownership forced employee to invest all or part of their wealth in the company, then they have already placed their human capital. This has the effect of increasing their firm-specific investment; the shares so acquired are generally not freely transferable only after a lockup period of several years, reducing the liquidity of their securities over external shareholders (...). The utility loss that 
results is even larger than the value of the shares acquired is very important to their relatively fixed value and their personal wealth....".

The same author considers that the double investment made by employee shareholders establish the usefulness of their presence in the system of corporate governance.

By participating in the functions of ratification and monitoring (Fama \& Jensen, 1983), they are especially urged to exercise effectively their control over the executives.

The use, therefore, of the "risk" argument that legitimate external shareholders as a natural right holder to control, the same way legitimate employee shareholders to participate in corporate governance as engaging both their human capital and financial capital, they increase even more their overall risk (Hollandts \& Guedri, 2007).

Employee become owners of a fraction of their firm capital become more involved in its management and performance (Desbrières, 1997). By becoming shareholders in their company, they incur in one hand, a residual risk in relation to their investment in human capital as employee and risk related to funds they have invested as shareholders, in other hand (Desbrières, 1997). They are therefore particularly encouraged to protect their investment by controlling opportunistic behaviour of managers, because they may suffer directly the consequences (Hollandts \& Guedri, 2007).

According (Desbrières, 2002), employee shareholders have various rights to effectively control their executives:

- As ownership and through voting rights used in the general assembly.

- As part of associations, the employee shareholders can increase their impact by joining independent structure unions and to better assert and defend their benefit.

- Via their representation in the control bodies (CA or CS).

The presence of employee shareholders in the control bodies gives them an additional informational advantage. Indeed, they can earn the information available to them as employee, and those obtained in the framework of meetings of shareholders.

This particular position should then allow them to effectively control managers, and compliance of decisions with their interests (Gharbi \& Lepers, 2008).

(Gamble, 2000) stresses that employee shareholders occupy a privileged position in the firm, seen that they enjoy physical proximity with the top management.

(Desbrières, 2002) suggested that the presence of employee shareholders in the control bodies is highly favourable to external shareholders. Their presence in the board or in the control board reduces the propensity that executives have of self-designation as a primary source of performance for the company.

For (Poulain-Rehm, 2006), participating in functions of ratification and monitoring (Fama \& Jensen, 1983), employee shareholders are well positioned to ensure compliance with their interests and to safeguard their dual investment.

According (Desbrières, 2002), the institutional participation of employee ownership in corporate governance is of most interest. On the one hand, anxious to protect their human capital and savings, employee shareholders have strong incentives to conduct effective control over managers.

Moreover, their independence regarding trade unions (the directors representing employee shareholders are not elected by all employee), they can act without any consideration of collective negotiation.

Ultimately, the employee shareholders can play a significant role in the system of corporate governance through a combination of the two statutes that allows them to have the informational advantages and physical proximity with the top management (Zolezzi, 2004).

However, their role as independent directors seems limited. Several authors support the hypothesis that employee shareholders cannot detach themselves from their dependence on executives and go up to counter their decisions (Gharbi, 2006).

Moreover, the ability of employee shareholders to ensure their role as "controller" seem to depend on their access to information and their weight in the control body that is weighted by the percentage of shares held (Desbrières, 2002).

"The power of employee shareholders is measured by the ability to influence decisions in AG (...) Their motivation to effectively control the executives is an increasing function of firm-specific investment in both human capital and equities" Desbrières (2002, p. 264). 


\subsection{The Limits of Government by Employee Shareholders}

Several authors consider employee ownership as a practice that would strengthen opportunism and managers rooting (Gordon \& Pound, 1990; Chaplinsky \& Niehaus, 1994; Pugh et al., 1999; Gamble, 2000; Gharbi, 2006; Gharbi \& Lepers, 2008; Hollandts et al., 2011).

Indeed, the hierarchical relationships and dependence which bind the employee shareholders to executives, effectively prevents them from exercising their duties as independent directors (Gharbi, 2006).

On the other hand, managers can implement several mechanisms to increase the dependence of employee to them, such as implicit contracts or possible cooperation strategies (Gamble, 2000).

Implicit contracts sold by the executives to employee shareholders can lead to promises of wage increases, evolution, and training or also by threats of layoffs. According to (Parrat, 1999), promises of promotion or salary increase aims to gain the support of employee in case of conflict of interest with shareholders.

Literature has raised two types of links that seem to be reflected according to the main objective of the executives, encouraging the establishment of employee ownership plans:

The first link, called an "indirect", suggests that executives set up the employee ownership plans with the objective of tax benefits attached to them (Autenne, 2005).

Executives tend to favour this type of remuneration compared to other forms such as salary increases (Vaughan-Whitehead, 1992).

The second link, which is considered "direct", suggests that by introduction of employee ownership executives seeking to protect themselves against possible hostile takeovers and preserve the autonomy of the enterprise and internal cohesion (Chang, 1990; Chaplinsky \& Niehaus, 1994; Park \& Song, 1995; Rauh, 2004).

Moreover, employee shareholders tend to oppose takeovers that they may be victims if they involve layoffs. Maintaining the existing management team, they ensure that their implicit contracts will be executed well. This produces a risk of collusion and mutual protection between managers and employee shareholders (Desbrières, 2002).

As highlighted Trébucq $(2002$, p112) “... dependence position of employee, eager to safeguard their jobs and human capital, can lead them to demand that their representative almost unwavering to support their managers. Thus the employee shareholders, fearing a possible dismissal, are exploited without their knowledge to thwart possible hostile takeovers. In these circumstances, the mechanisms of corporate governance ensuring external discipline of managers, through the financial market and labour market, are no longer operative."

Thus, the presence of representatives of employee shareholders greatly reduces the effectiveness of the monitoring and evaluation devoted to corporate governance (Trébucq, 2002).

Several empirical studies confirm the use of employee ownership for purposes of rooting by managers. Thus, (Chang, 1990) showed that the introduction of ESOP (Employee stock ownership plan) was seen as a defensive strategy of managerial rooting. The results confirm the unfavourable market reaction when the ESOP follows an attempted of takeover.

(Gordon \& Pound, 1990) find that the announcement of the establishment of an ESOP would be the signal of a future takeover attempt. The results of their study of event, and those of (Chang, \& Mayers, 1992) and (Conte, Blasi, Kruse, \& Jampani, 1996), support the hypothesis of managerial rooting.

(Chaplinsky \& Niehaus, 1994) and (Park \& Song, 1995) clearly confirmed the use of employee ownership plans for defensive purposes and rooting.

(Pugh, Jahera, \& Oswald, 1999) observed a simultaneous use of employee ownership and debt in companies likely to be subject to a public takeover bid. (Gamble, 2000) notes, a restriction of the risk of external takeovers for companies with ESOP.

Generally, employee ownership, as a defensive mechanism, strengthens the position of executive's hip by limiting the risk of hostile takeovers (Pendleton et al., 1998; Pendleton, 2001).

The recent study of (Hollandts, Guedri, \& Aubert, 2011) sought to determine the history of representation of employee shareholders on the board, confirms the assumption of management rooting.

Overall, the conclusions on corporate governance by employee shareholders are controversial. In one hand, employee ownership is a tool of corporate governance, insofar as its incentive component may induce employee to ensure effective control on managers to protect their double investment in human capital and financial capital. 
Moreover, the participation of employee shareholders in decision-making weakens control bodies of managers and, in particular, the financial market (Gordon \& Pound, 1990). In this sense, employee ownership can be used by the management team as an anti-takeover (Gamble, 2000; Gharbi, 2006).

In absence of a consensus on the theoretical and empirical effects of a government by the employee shareholders on economic performance, we look through a quantitative study, the case of an 'exclusive' representation of employee shareholders on the board of directors or of trustees, and this, from a sample belonging to the company SBF250.

\section{Empirical Analysis}

\subsection{Methodology}

Our empirical study covers a sample of firms belonging to the SBF 250 over the period of 2000-2010. Enterprises not having a continuous presence during this period were therefore withdrawn.

We selected only companies with employee ownership plans during the period studied.

A total of 90 have an employee ownership plans, including 15 with one or more directors representing employee shareholders issued from an association of employee shareholders, or a mutual fund (exclusive representation).

However, we have 40 firms without exclusive representation of employee shareholders.

Both groups in our sample are as follows:

- Group 1: composed by 15 companies with exclusive representation of employee shareholders.

- Group 2: composed by 40 companies without exclusive representation of employee shareholders.

To determine the effects of the presence of directors representing employee shareholders on value creation, our approach is to compare the economic performance of two business groups.

To this end, we opted for an approach based on econometric methodology "estimate panel data". This bi-dimensional technique allows appreciating, simultaneously, the dynamic behaviour and their possible heterogeneity. This is not the case with time series or cross-sections. It also takes into account the influence of unobservable characteristics of individuals about their behaviours when they remain stable over time (Sevestre, 2002).

Therefore, our sample panel totalize 605 observations (55 firms x 11 years).

Data were collected through several sources. Those relating to the characteristics of the employee shareholders and directors representing employee shareholders are from the database who's who in France and through the annual filings of companies filed nearby the AMF (authority of financial market).

The data on economic performance and those related to control variables were collected primarily through the reference documents and databases and Diane Thomson One Banker.

\section{Operationalization of variables}

\section{Independent variable}

Our research suggests that the involvement of employee ownership in corporate governance influences economic performance.

Indeed, the presence of directors holding shares in the company promotes aligning their interests with those of external shareholders (Jensen \& Warner, 1988). Effectively controlling the managers, directors would work in their own interests identified with that of other shareholders.

The agency theory emphasizes the importance of stock ownership by members of the board on the effectiveness of control by the body (Hillman \& Dalziel, 2003). Thus, the financial involvement of directors and the exposure of their personal assets to business risk induce them to effectively monitor management (Kosnik, 1990; Walsh \& Seward, 1990, Jensen \& Warner, 1988, Shleifer \& Vishny, 1986).

In this context, the employee shareholders, due to their dual financial and human investment, may represent an effective internal governance mechanism. By electing representatives among themselves, they can ensure that managers operate in line with their interests.

Indeed, they are even more incentive to monitor managers when the number of shares they personally hold is important (Hillman \& Dalziel, 2003).

According (Desbrières, 1997), the additional risk incurred through investment in share ownership should be associated with better control. 
In this context, a first measure of the effectiveness of control undertaken by representatives of employee shareholders in the board of directors, can be envisaged through a binary variable that takes the value 1 if the firm has at least one director representing employee shareholders from a combination of employee shareholders or a mutual fund share ownership, and 0 in the absence of such a representation (Hollandts, Guedri, \& Aubert, 2011). However, the number of employees shareholders directors will be appreciated by a continuous variable (D’Arcimoles \& Trébucq, 2003; Hollandts, 2007).

However, if we consider the analysis of (Hollandts, Guedri, \& Aubert, 2011), for the same level of financial capital investment, the efficiency of directors representing employee shareholders within control bodies depend on their human capital endowment. Indeed, the importance of human capital, its specificity to the company and its low redeploy ability on the labour market (Blair, Kruse, \& Blasi, 2000) play a role in the effectiveness of control by employee shareholders directors.

According to theorists, younger workers are better endowed with human capital (Degeorge et al., 2004). Regarding the degree of specificity to the company, economists often retain, as a measure, the employee's seniority within the company.

Given these observations, we retain the seniority for directors representing employee shareholders in their company and their ages, as two continuous variables.

On the other hand, the literature emphasizes the importance of seniority as directors (Hollandts, Guedri, \& Aubert, 2011). Indeed, this seniority promotes greater organizational commitment (Buchanan, 1974) of the directors, a shared understanding of the rules of the group (Alderfer, 1986 ) and a higher resistance to pressure from external shareholders (Kosnik, 1987) .

However, some authors oppose such an analysis, considering the seniority of the directors as a factor facilitating the management rooting (Hermalin \& Weisbach, 1988).

The role and capacity to influence directors representing employee shareholders are also related to the proportion of capital held by employees. "The power of employee shareholders is measured by the ability to influence decisions in $A G$ (...) Their motivation to effectively control the managers is an increasing function of firm-specific investment in both human capital and equities" Desbrières (2002, p.264).

The importance of the share capital held by employees (often measured by the percentage of employee ownership) is related to the capital structure of the company. The presence of an external shareholder holding a blocking minority (33\% of capital according to d'Arcimole and Trébucq, 2003; Desbrières, 2002; Trébucq, 2002; Hollandts, 2007) is not without influence on the role that may have employee shareholders in the company.

\section{Summary of independent variables}

- Presence of exclusives directors representing employee shareholders (variable PADSA)

- Number of exclusives directors representing employee shareholders (variable NADSA)

- The seniority of the directors within the company (variable AADSA)

- The seniority in the position of directors (variable AADSAA)

- The age of the employee shareholders directors (variable AGADSA)

- Rate of employee ownership (TAS)

Dependent variables: the economic performance

Empirical works examining the financial performance generally rely on measures from the accounting and / or measures likely market.

Some authors prefer a performance based on market values such as market capitalization relative or absolute (Jensen \& Murphy, 1990) or annual stock return or relative (Murphy, 1985; Benston, 1985; De Fusco et al., 1990).

Others rely on indicators like accounting, such as return on equity (Finkelstein \& Hambrick, 1988) or the change in net income or operating income (McGuire, 1963).

The advantage of accounting indicators is that they provide a more relevant measure of economic performance of the firm. Their disadvantage is that they are subject to managerial manipulation (Oswald \& Jahera, 1991).

On other hand, the stock market measures are less subject to managerial manipulation, but they represent a specific assessment to the investor and does not reveal the economic reality of the business (Griffin \& Mahon, 
1997).

To better evaluate the financial performance, we integrate the two measures at a time (Dondi, 1992; Trébucq, 2002; d'Arcimoles \& Trébucq, 2003; Hollandts, 2007).

- ROA (Return On Asset) is the economic profitability which measures in percentage the ratio between net income and net assets mobilized in the activity (McGuire et al, 1963).

- PBR (Price to book ratio): measures the stock market performance (Hollandts, 2007; D'Arcimoles and Trébucq, 2003; Hollandts et al., 2011).

\section{Control variables}

The study of the relationship between the representation of employee shareholders in the control bodies, and financial performance, may not be made without the introduction of a set of control variables to avoid statistical bias. Taking into account the effect size and activity sector is essential for a comparative view of the financial performance of companies studied. A small size can indeed result in greater control of shareholders on the actions of executives (Poulain-Rehm, 2006).

Our study includes five control variables to improve the external validity of results (Thiétardt \& Coll, 1999).

The size was operationalized as the logarithm of turnover and workforce.

The company performance should be evaluated in relation to the performance of the industry. The inclusion of this variable is made according to the nomenclature of Euronext.

We segmented firms into two main business sectors:

S0: service + trade sector

S1: industry sector

We retain a variable measuring the presence / absence of an external shareholder holding a blocking minority (33\% of capital and according to d'Arcimoles and Trébucq, 2003; Desbrières, 2002; Trébucq, 2002; Hollandts, 2007).

To measure the intensity of the relationship between employee ownership and financial performance, the dimension 'time' represented by the duration of the presence of employee ownership seems essential (Klein and Hall, 1988; Hollandts, 2007, D ‘Arcimoles and Trébucq, 2003).

Summary of control variables

- Annual Turnover (CA)

- Employees (N)

- Sector of activities (S)

- The presence / absence of external majority shareholder (variable EAME)

- Duration of employee ownership (DAS)

\subsection{Analysis and Discussion of Results}

Our research aims to test the effects of the representation of employee shareholders in the board of directors or board of trustees on the economic performance of the company. To determine the nature of these effects, we established a linear model as independent variables with the performance of the company.

The results of both models (PBR and ROA) show the existence of a significant negative relationship between the variables PADSA (presence / absence of directors representing employee shareholders) and NASDA (number of directors representing employee shareholders) and the performance of the companies studied.

Representation of employee shareholders in the control bodies, therefore, influences negatively the economic performance of the firm. This result seems to confirm the predictions of major part of the literature.

The regressions show that there is a negative relationship between the rate of employee ownership (TAS) and stock market performance (PBR). This result agrees with the theoretical and empirical findings of several French and Anglo-Saxon studies. However, it conflicts with some studies, including that of (Hollandts \& Guedri, 2007) suggesting the existence of a curvilinear relationship between the two variables.

We record significance at $10 \%$ for the service sector and trade regarding to ROA. However, other control variables are not significant.

The human capital endowment measured by the age of the directors, his seniority within the company as well as 
on the board, is negatively related to performance indicators. This result is consistent with the progress of some authors considering the seniority of the directors as a factor facilitating the management rooting (Hermalin \& Weisbach, 1988).

Table 1. Regression results

\begin{tabular}{|c|c|c|c|c|c|c|}
\hline \multirow{2}{*}{ Variables } & \multicolumn{3}{|l|}{ PBR } & \multicolumn{3}{|l|}{ ROA } \\
\hline & Value estimated & Error type & $\operatorname{Pr}>|t|$ & Value estimated & Error type & $\operatorname{Pr}>|t|$ \\
\hline PADSA & -2.1985 & 0.7902 & $0.0056 * * *$ & -1.976904 & 1.2411 & $0.0037 * * *$ \\
\hline NADSA & -0.2875 & 1.3662 & $0.0923 *$ & -0.16629 & 1.0207 & $0.0324 * *$ \\
\hline TAS & -0.1623 & 2.1885 & $0.0639 *$ & 0.51204 & 0.225 & 0.7542 \\
\hline DAS & 0.2836 & 0.5762 & 0.6227 & -0.23236 & 2.4904 & 0.1257 \\
\hline ASAE & -0.8609 & 3.4322 & $0.0529 *$ & -1.62273 & 1.3232 & 0.4564 \\
\hline ASAC & -0.1123 & 0.9185 & $0.0660 *$ & -4.84723 & 1.3230 & 0.2631 \\
\hline AGSA & -0.8442 & 1.1482 & $0.0235^{* *}$ & -0.23365 & 2.5271 & $0.0720 *$ \\
\hline EAME & -0.3412 & 2.3061 & 0.2016 & 3.3287 & 3.4528 & 0.1033 \\
\hline $\mathbf{C A}$ & -0.41923 & 1.1232 & 0.9832 & 0.1226 & 4.3211 & 0.2713 \\
\hline $\mathbf{N}$ & -0.5921 & 0.3882 & 0.4971 & -4.21730 & 3.3011 & 0.3420 \\
\hline So & 0.4924 & 0.7344 & $0.0811^{*}$ & 1.9352 & 5.1021 & 0.1661 \\
\hline S1 & -0.31948 & 0.7192 & 0.6571 & -12.07514 & 3.2300 & 0.0002 \\
\hline
\end{tabular}

Note: ***,**, * Significance levels: $1 \%, 5 \%, 10 \%$.

We interpret these results as confirmation of the use of employee ownership by managers for purposes of rooting, which can be detrimental to value creation.

Thus, the representation of employee shareholders causes a reduction in the efficiency of the control system because of the hierarchical dependence of the directors representing employee shareholders (Hollandts et al., 2011; Gharbi \& Lepers, 2008). These can have a negative impact on business objectives by fostering opportunistic behaviours of managers. Companies involving employee shareholders in decision-making are generally less efficient than those being devoid (Alchian \& Demetz, 1972; Furubotn, 1976; Jensen \& Meckling, 1979).

(Gamble, 2000) emphasizes that employees are not sufficiently independent of managers and that implicit contracts based on tacit cooperation relations between both parties. This bilateral rooting (Faleye, Mehrotra, \& Morck, 2006) causes a decrease in the intensity of the control exercised by the directors representing employee shareholders on the executives, in return for guarantees of mainly employment and wages (Gharbi \& Lepers, 2008).

Other authors highlight the opportunity for executives to use the share capital held by employees, for purposes of rooting (Hollandts, 2007; Gharbi, 2006; Gharbi \& Lepers, 2008, Chang \& Mayers, 1992; Gordon \& Pound, 1990; Chaplinsky \& Niehaus, 1994). It is used as an anti-external takeover and mechanically increasing the power of managers. For (Gordon \& Pound, 1990), employee ownership is a mean of manager's protection, reducing the chance of a takeover sanctioning poor performance.

Several empirical studies confirm the use of employee ownership by executives for rooting:

(Rauh, 2004) shows a clear and immediate goal to create employee ownership is to erect barriers to hostile takeovers and, therefore, better protect the heads of risks eviction and replacement.

(Pugh, Jahera, \& Oswald, 1999) note that the ESOP increases the authority of managers in the firm, if they are considered actions "friends." The new shareholders are seen in this case, as allies of managers.

Moreover, (Chang, 1990) states that in the presence of defensive ESOP, the shareholders believe that the voting rights attached to shares are controlled by executives who, pursuing a strategy of rooting, looking to escape the discipline of market for corporate control.

The managers rooting hypothesis may also explain the empirical results obtained by (Dondi, 1992). Indeed, it seems accepted that equity is used by executives for rooting.

The investigation of the (COB-Altédia, 1999) confirms that almost half of surveyed French managers readily admit that equity is a particularly effective way to escape the external discipline of hostile takeovers.

Representation of employee shareholders in the control bodies has an effect on the behaviour of managers. The 
latter, using the voting rights attached to shares held by employees, can strengthen their position in the company and consolidate their influence. They can give more willingly to wastly policies that could lead to a significant reduction in financial performance (Trébucq, 2002).

Recent work by (Hollandts, Guedri, \& Aubert, 2011), covering a sample of companies in the SBF 250, confirm the assumption of managers rooting in case of employee shareholders representation in the board. The author shows the existence of a relationship between the degree of management rooting and the presence of directors representing employee shareholders.

\section{Conclusion}

The objective of our article was to contribute to a better understanding of the issue of corporate governance in the presence of directors representing employee shareholders. As the study covered a sample of French companies belonging to the SBF 250, confirms the hypothesis that use of employee ownership by executives for rooting. This managerial flexibility comes at the expense of value creation.

On a theoretical level, the results of our study meet the work rejecting the idea of a positive contribution of directors representing employee shareholders in the company's performance through their presence in decision-making.

Indeed, the exclusive representatives of employee shareholders tend to join the coalition of executives (Gharbi, 2006) and therefore facilitate their rooting.

Opportunistic behaviour (managers and employees) come thus; reduce the economic performance of the company. These results are consistent with theoretical predictions and support the conclusions of a large frame of empirical literature rejecting a possible positive effect of employee ownership on firm performance due to the use of this mechanism for rooting (Gharbi \& Lepers, 2008; Gharbi, 2006; Chaplinsky \& Niehaus, 1994; Chang \& Mayers, 1992; Gordon \& Pound, 1990). Indeed, when employee ownership is coupled to a representation in corporate governance, it offers an additional lever rooting executives (Gordon \& Pound, 1990: Pugh et al., 1999).

On the managerial level, our article attempts to provide some recommendations that integrate within the potential role of employee ownership in corporate governance. Indeed, the law of December 30, 2006 requires boards of directors or board of trustees to welcome directors representing employee shareholders, in this context, it should determine the conditions that guarantee the effectiveness of the institutional dimension of employee ownership. In this regard, we suggest that the preconditions for effectiveness of this representation are related to the personal incentives of the directors representing employee shareholders. We also consider the institutional context is likely to modulate the efficiency of the control exercised by the directors representing employee shareholders (Hollandts, Aubert, \& Eminet, 2008).

However, as part of our research, we were not able to include some variables that are not without influence on the nature of the relationship between the representation of employee shareholders and firm performance, including personal property (structure and composition). Indeed, a director who invested much of his personal assets in employee ownership would be more incentive to exercise effectively its supervisory role. However, and due to the unavailability of such data, these variables could not be exploited.

The majority of works have often adopted similar methodologies, making comparisons between companies with employee ownership or representation of employee shareholders, to others who do not. It would be very useful to conduct longitudinal studies to track the evolution of economic and social performance of the business before and after the introduction of employee ownership.

\section{References}

Aglietta, M., \& Reberioux, A. (2004). Dérives du capitalisme financier. Paris: Albin Michel Economie.

Alderfer, C. (1986). The invisible director on corporate boards. Harvard Business Review, 64(6), 38-50.

Autenne, A. (2005). Analyse économique du droit de l'actionnariat salarié. Bruxelles: Bruylant Bibliothèque de la Faculté de Droit de l'Université Catholique de Louvain.

Blair, M., Kruse, D., \& Blasi, J. (2000). Employee Ownership: an Unstable Form or A Stabilizing Force. In M. M. Kochan (Ed.), The New Relationship: Human Capital in the American Corporation. Washington DC: Brookings lnstitution Press.

Buchanan, B. (1974). Building organizational commitment: The socialization of managers in work organizations. Administrative Science Quarterly, 19, 533-546. http://dx.doi.org/10.2307/2391809 
Chang, S. (1990). Employee Stock Ownership and Shareholder Wealth: an Empirical Investigation. Financial Management, 19(1), 48-58. http://dx.doi.org/10.2307/3666036

Chang, S., \& Mayers, D. (1992). Managerial Vote Ownership and Shareholder Wealth. Journal of Financial Economics, 32, 103-131. http://dx.doi.org/10.1016/0304-405X(92)90027-U

Chaplinsky, S., \& Niehaus, G. (1994). The Role of ESOPs in Takeover Contests. Journal of Finance, 49(4), 1451-1470. http://dx.doi.org/10.1111/j.1540-6261.1994.tb02461.x

Charreaux, G. (1997). Mode de contrôle des dirigeants et performance des firmes. Le gouvernement des entreprises.

COB-Altédia. (1999). L'actionnariat salarié. Paris: COB-Altédia.

Conte, M., Blasi, J., Kruse, D., \& Jampani, R. (1996). Financial returns of public ESOP companies: investors effects vs. Manager effect. Financial Analyst Journal, 52, 50-60. http://dx.doi.org/10.2469/faj.v52.n4.2011

D’Arcimoles, C. H., \& Trébucq, S. (2003). Une approche du rôle de l'actionnariat salarié dans la performance et le risque des entreprises françaises. Revue de Gestion des Ressources Humaines (48).

Desbrières, P. (1997). Le rôle de l'actionnariat des salariés non-dirigeants dans le système de gouvernement de l'entreprise. (C. G, Ed.) Recherche en Gestion.

Desbrières, P. (2002). Les actionnaires salariés. Revue Française de Gestion, 28(141), 255-281.

Dondi, J. (1992). L'actionnariat des salariés dans les entreprises françaises: résultats empiriques. In Economica, Annales du Management (pp. 191-206). IAE de Nancy: Le Duff R. et J. Allouche.

Faleye, O., Mehrotra, V., \& Morck, R. (2006). When Labor Has a Voice in Corporate Governance. Journal of Financial and Quantitative Analysis, 41(3), 489-510. http://dx.doi.org/10.1017/S0022109000002519

Fama, E. (1980). Agency problems and the theory of the firm. Journal of Political Economy, 88, 50-62. http://dx.doi.org/10.1086/260866

Fama, E., \& Jensen, M. (1983). Separation of Ownership and Control. Journal of Law and Economics, 26, 301-326. http://dx.doi.org/10.1086/467037

Finkelstein, S., \& Hambrick, D. C. (1988). Chief Executive Compensation: a synthesis and reconciliation. Strategic Management Journal, 9. http://dx.doi.org/10.1002/smj.4250090603

Gamble, J. (2000). Management Commitment to innovation and ESOP Stock Concentration. Journal of Business Venturing, 15, 433-447. http://dx.doi.org/10.1016/S0883-9026(99)00037-3

Gharbi, H. (2006). Actionnariat salarié et enracinement des dirigeants. Paris: Université Paris Dauphine.

Gharbi, H., \& Lepers, X. (2008). Actionnariat salarié et enracinement des dirigeants: un essai de compréhension. Revue Innovation, 1(27). http://dx.doi.org/10.3917/inno.027.0121

Gordon, L., \& Pound, J. (1990). ESOPs and Corporate Control. Journal of Financial Economics, 27, 525-555. http://dx.doi.org/10.1016/0304-405X(90)90066-9

Griffin, J. J., \& Mahon, J. F. (1997). The Corporate social performance and corporate financial performance debate. Business and Society, 36(1).

Hansmann, H. (1996). The Ownership of Enterprise. Belknap Press of Harvard University Press.

Hermalin, B., \& Weisbach, M. (1988). The determinants of board composition. The Rand Journal of Economics, 19, 589-606. http://dx.doi.org/10.2307/2555459

Hillman, A., \& Dalziel, T. (2003). Board of Directors and Firm Performance: Integrating Agency and Resource Dependent Perspectives. Academy of Management Review, 8(23), 383-396. http://dx.doi.org/10.5465/AMR.2003.10196729

Hollandts, X., \& Aubert, N. (2011). La représentation obligatoire des actionnaires salariés au conseil d'administration: un état des lieux. Gestion 2000, 28(6), 15-26.

Hollandts, X., \& Guedri, Z. (2007). Effet modérateur de la présence d'administrateurs salariés sur la relation actionnariat salarié-performance: une analyse empirique. XVIe Conférence Internationale de Management Stratégique. Montréal.

Hollandts, X., Aubert, N., \& Eminet, A. (2008). La représentation obligatoire des actionnaires salariés au conseil d'administration: enjeux et conditions d'efficacité. Université Montesquieu Bordeaux-IV. 
Bordeaux: 7e Congrès International de Gouvernance.

Hollandts, X., Guedri, Z., \& Aubert, N. (2011). Les déterminants de la représentation des actionnaires salariés au Conseil d'administration ou de surveillance. Management International, 15(4), 69-83. http://dx.doi.org/10.7202/1006192ar

Jensen, M., \& Meckling, W. (1976). Theory of the Firm: Managerial Behavior, Agency Costs and Ownership $\begin{array}{lllll}\text { Structure. Journal of Financial } & \text { Economics, } & 3(4), & 305-360 .\end{array}$ http://dx.doi.org/10.1016/0304-405X(76)90026-X

Jensen, M., \& Murphy, K. (1990). Performance Pay and Top-Management Incentives. Journal of Political Economy, 98(2). http://dx.doi.org/10.1086/261677

Jensen, M., \& Warner, J. (1988). The distribution of power among corporate managers. Journal of Financial Economics, 20, 3-24. http://dx.doi.org/10.1016/0304-405X(88)90038-4

Kosnik, R. (1987). Greenmail: A study of board performance in corporate governance. Administrative Science Quarterly, 32, 163-185. http://dx.doi.org/10.2307/2393124

McGuire, J. W. (1963). Business and Society. New York: MacGraw-Hill.

Oswald, S., \& Jahera, J. (1991). The influence of Ownership on Performance: an Empirical Study. Strategic Management Journal, 12(4), 321-326. http://dx.doi.org/10.1002/smj.4250120407

Park, S., \& Song, M. (1995). Employee Stock Ownership Plans, Firm Performance, and Monitoring by Outside Block holders. Financial Management, 24(4), 52-65. http://dx.doi.org/10.2307/3665950

Parrat, F. (1999). Le gouvernement d'entreprise: ce qui a déjà changé, ce qui va encore évoluer. Maxima.

Poulain-Rehm, T. (2006). AFFI, (pp. L'actionnariat des salariés en France, un facteur de création de valeur?). Poitiers.

Pugh, W., Jahera, J., \& Oswald, S. (1999). ESOPs, Takeover Protection, and Corporate Decision-Making. Journal of Economics and Finance, 23(2), 170-185. http://dx.doi.org/10.1007/BF02745951

Rauh, J. (2004). Own Company Stock in defined contribution pension plans: A takeover defense. Working paper.

Sevestre, P. (2002). Économétrie des données de panel. Paris: Dunod.

Thiétardt, R. A., \& Coll. (1999). Méthodes de recherche en management. Paris: Dunod.

Trébucq, S. (2002). L'actionnariat salarié dans les entreprises familiales du SBF250: un outil de création de valeur? Finance Contrôle Stratégie, 5(4), 107-135.

Vaughan-Whitehead, D. (1992). Intéressement, participation, actionnariat: impacts économiques dans l'entreprise. Paris: Économica.

Wirtz, P. (2000). Mental Patterns, Corporate Finance and Institutional Evolution: The Case of the French Corporate Governance System. (U. d. Dijon, Ed.) Working paper n $n^{\circ} 1000101$ LEG-FARGO.

Zolezzi, G. (2004). L'actionnariat salarié influent face aux théories des droits de propriété et de la gouvernance partenariale. Métamorphoses des Organisations. Nancy: GREFIGE.

Note

Note 1. According to the French Federation of Associations of shareholders and former employee. 